\title{
MIR150 Gene
}

National Cancer Institute

\section{Source}

National Cancer Institute. MIR150 Gene. NCI Thesaurus. Code C105985.

This gene may be involved in the regulation of protein expression. 